\title{
Chemical Diversity, Biological Activity, and Genetic Aspects of Three Ocotea Species from the Amazon
}

\author{
Joyce Kelly da Silva ${ }^{1}$, Rafaela da Trindade ${ }^{1}$, Edith Cibelle Moreira ${ }^{2}$, José Guilherme S. Maia ${ }^{3}$, \\ Noura S. Dosoky ${ }^{4}$, Rebecca S. Miller ${ }^{5}$, Leland J. Cseke ${ }^{5}$ and William N. Setzer ${ }^{4, *}$ \\ 1 Programa de Pós-Graduação em Biotecnologia, Universidade Federal do Pará, 66075-900 Belém, Brazil; \\ joycekellys@ufpa.br (J.K.d.S.); rcabral@ufpa.br (R.d.T.) \\ 2 Instituto de Estudos em Saúde e Biológicas, Universidade Federal do Sul e Sudeste do Pará, \\ 68501-970 Marabá, Brazil; cibelle@unifesspa.edu.br \\ 3 Programa de Pós-Graduação em Recursos Naturais da Amazônia, Universidade Federal do Oeste do Pará, \\ 68035-110 Santarém, Brazil; gmaia@ufpa.br \\ 4 Department of Chemistry, University of Alabama in Huntsville, Huntsville, AL 35899, USA; \\ nouradosoky@yahoo.com \\ 5 Department of Biological Sciences, University of Alabama in Huntsville, Huntsville, AL 35899, USA; \\ rsm0024@uah.edu (R.S.M.); csekel@uah.edu (L.J.C.) \\ * Correspondence: wsetzer@chemistry.uah.edu; Tel.: +1-256-824-6519
}

Academic Editors: Vincenzo De Feo, Laura De Martino and Carmen Formisano Received: 15 March 2017; Accepted: 10 May 2017; Published: 18 May 2017

\begin{abstract}
Ocotea species present economic importance and biological activities attributed to their essential oils (EOs) and extracts. For this reason, various strategies have been developed for their conservation. The chemical compositions of the essential oils and matK DNA sequences of O. caudata, O. cujumary, and O. caniculata were subjected to comparison with data from O. floribunda, $O$. veraguensis, and $O$. whitei, previously reported. The multivariate analysis of chemical composition classified the EOs into two main clusters. Group I was characterized by the presence of $\alpha$-pinene (9.8-22.5\%) and $\beta$-pinene (9.7-21.3\%) and it includes O. caudata, O. whitei, and O. floribunda. In group II, the oils of $O$. cujumary and $O$. caniculata showed high similarity due amounts of $\beta$-caryophyllene (22.2\% and $18.9 \%$, respectively). The EO of O.veraguensis, rich in $p$-cymene $(19.8 \%)$, showed minor similarity among all samples. The oils displayed promising antimicrobial and cytotoxic activities against Escherichia coli (minimum inhibitory concentration (MIC) $<19.5 \mu \mathrm{g} \cdot \mathrm{mL}^{-1}$ ) and MCF-7 cells (median inhibitory concentration $\left(\mathrm{IC}_{50}\right) \cong 65.0 \mu \mathrm{g} \cdot \mathrm{mL}^{-1}$ ), respectively. The analysis of matK gene displayed a good correlation with the main class of chemical compounds present in the EOs. However, the matK gene data did not show correlation with specific compounds.
\end{abstract}

Keywords: Lauraceae; volatile compounds; terpenes; matK gene; phylogenetic analysis

\section{Introduction}

The genus Ocotea is not a monophyletic group of the Lauraceae, which includes about 400 species occurring mostly in tropical and subtropical regions (Central and South America, the West Indies, and Africa) [1,2]. These species present alternate penninerved leaves; inflorescenses thyrsopaniculate to botryoid. Flowers are trimerous, bisexual, polygamous, or unisexual; tepals equal, rarely persistent on the rim; nine fertile stamens, the third whorl with glands; anthers with four loculos; receptacle very small and deeply tubular; in male flowers, rudimentary ovary to absent; fruit and cupule extremely variable in size and shape [1]. It is a very variable genus morphologically, being the largest genus in the Neotropics, with 170 species occurring in Brazil [3,4].

The economic importance of Ocotea species in the Amazon region has been related to numerous applications such as the use of their wood in lightweight construction and luxury furniture [5]. 
Phytochemical studies reported the occurrence of benzylisoquinoline alkaloids, neolignans, catechins from leaves and bark of $O$. porosa [6,7]; aporphine alkaloids from leaves of $O$. macrophylla; flavonols from O. vellosiana; and eudesmane sesquiterpenoids from O. corymbosa [8-10]. The volatile chemical profiles of Ocotea species are characterized by high concentrations of phenylpropanoids and terpenoids (hydrocarbons or oxygenated) [11,12].

Many studies have been reported on the biological activities of Ocotea metabolites: the alkaloid reticuline isolated from extract of $O$. duckei showed potent central nervous system depressant action [13]. (-)-Caaverine, a noraporphine alkaloid isolated from O. lancifolia, has shown high antiprotozoal activity against Leishmania and Trypanosoma cruzi parasites [14]. The chloroform fraction obtained from an extract of fruits of O. puberula and the alkaloid dicentrine displayed antinociceptive effects [15]. The butanolides isolated from roots of $O$. macrocarpa showed good cytotoxic activities against the A2780 ovarian cell line [16]. The flavonoids of $O$. notata showed antimycobacterial activity and ability to inhibit NO production by macrophages [17]. The essential oil of O. quixos, rich in trans-cinnamaldehyde and methyl cinnamate, showed anti-inflammatory properties in vitro and in vivo models [18]. Studies on the chemical characteristics of the species O. caudata, O. cujumary, and O. caniculata are rare and important because Ocotea species are classified as threatened to extinction by the Brazilian List and the risk of extinction is increased due the reduction of genetic variability $[19,20]$ so knowledge of the genetic diversity is necessary for our understanding of the factors that determine essential oil quantity and quality in these economically important species [21].

\section{Results and Discussion}

\subsection{Essential Oil Chemical Composition}

The essential oil (EO) of Ocotea species provided different yields and the higher yields were found in the leaf EO for all samples (0.7-0.8\%) (Table 1$)$.

Table 1. Collection data and essential oil yield of the samples of Ocotea occurring in Caxiuanã National Forest, Amazon, Brazil.

\begin{tabular}{cccccc}
\hline Species & Geographic Coordinate & Voucher & Plant Material & Sample & Oil Yield (\%) \\
\hline \multirow{2}{*}{ O. caudata } & $\mathrm{S} 01.0^{\circ} 44.0^{\prime} 18.8^{\prime \prime}$ & MG & Leaves & Cau-L & 0.7 \\
& $\mathrm{~W} 51.0^{\circ} 27.0^{\prime} 27.4^{\prime \prime}$ & 216263 & Branches & Cau-B & 0.1 \\
\hline \multirow{2}{*}{ O. cujumary } & $\mathrm{S} 01.0^{\circ} 44.0^{\prime} 14.1^{\prime \prime}$ & $\mathrm{MG}$ & Leaves & Cuj-L & 0.8 \\
& $\mathrm{~W} 51.0^{\circ} 27.0^{\prime} 20.4^{\prime \prime}$ & 216269 & Branches & Cuj-B & 0.5 \\
\hline \multirow{2}{*}{ O. caniculata } & $\mathrm{S} 01.0^{\circ} 44.0^{\prime} 14.1^{\prime \prime}$ & $\mathrm{MG}$ & Leaves & Can-L & 0.7 \\
& $\mathrm{~W} 51.0^{\circ} 27.0^{\prime} 20.4^{\prime \prime}$ & 216262 & Branches & Can-B & 0.2 \\
\hline
\end{tabular}

The most representative compounds class was sesquiterpene hydrocarbons (56.3-82.0\%) in all samples from Caxianuã Forest (Figure 1). The O. caudata oils showed different chemical profiles in the tissues; in the EO from leaves (Cau-L) the monoterpene hydrocarbons $(21.5 \%)$ were present, while in the branches (Cau-B) there was a high accumulation of oxygenated sesquiterpenoids (35.9\%). The EO of O. cujumary leaves (Cuj-L) showed higher concentrations of oxygenated sesquiterpenoids $(25.8 \%)$ than branches (Cuj-B, $4.0 \%$ ), which showed significant amounts of monoterpene hydrocarbons $(22.7 \%)$ and fatty acid derivatives (34.6\%). The O. caniculata oils showed amounts of phenylpropanoids, especially in the branches (Can-B, $15.5 \%$ ). Seventy volatile components were identified, comprising approximately $95.1 \%$ of the total composition of the oils (Table 2 ). 


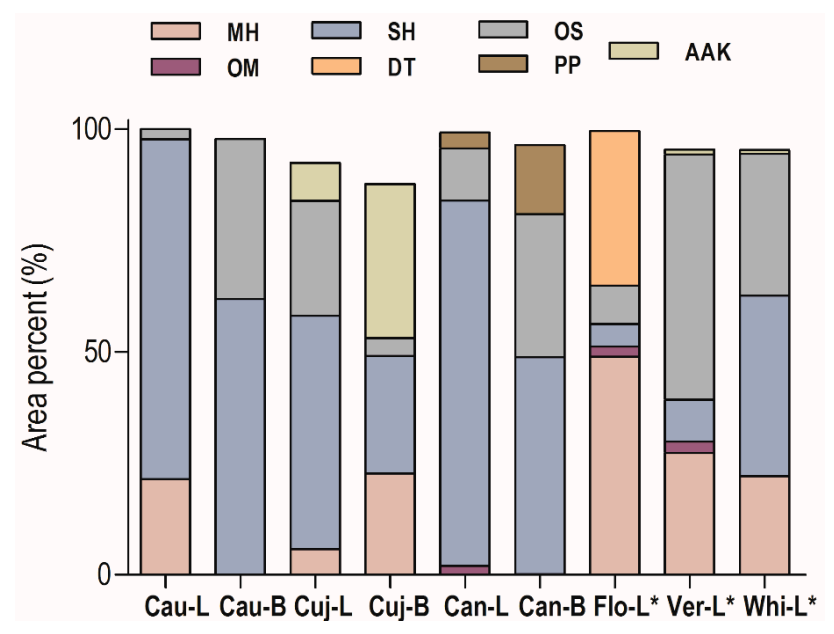

Figure 1. Distribution of compound classes in essential oils (Eos) of Ocotea species. Monoterpene hydrocarbons (MH), Oxygenated monoterpenoids (OM), Sesquiterpene hydrocarbons (SH), Oxygenated sesquiterpenoids (OS), Diterpenes (DT), Phenylpropanoids (PP), Alkanes, aldehydes, and ketones (AAK). O. floribunda leaves (Flo-L), O. veraguensis leaves (Ver-L), O. whitei leaves (Whi-L); ${ }^{*}$ Literature data [22]. Cau-L (O. caudata leaves); Cau-B (O. caudata bark); Cuj-L (O. cujimary leaves); Cuj-B (O. cujimary bark); Can-L (O. caniculata leaves); Can-B (O. caniculata bark).

The main compounds identified in O. caudata oils were bicyclogermacrene $(29.6 \%)$, germacrene $\mathrm{D}(19.9 \%), \beta$-caryophyllene $(9.6 \%), \alpha$-pinene $(9.8 \%)$, and $\beta$-pinene $(9.7 \%)$ in the leaves (Cau-L) and $\delta$-cadinene $(13.8 \%)$, germacrene $\mathrm{D}(8.9 \%)$, and $\alpha$-muurulol $(7.8 \%)$ in the branches (Cau-B). $\beta$-Caryophyllene, germacrene-D, $\alpha$-pinene, and $\beta$-pinene were the principal common constituents of the EOs of leaves of Ocotea floribunda, O. holdridgeana, O. meziana, O. sinuata, O. tonduzii, O. valeriana, $O$. veraguensis, O. whitei, and two new undescribed Ocotea species [22].

In addition, these chemical compounds were identified in the leaves in other Lauraceae species. The EO of leaves of Endlicheria arenosa was dominated by bicyclogermacrene (42.2\%), germacrene D $(12.5 \%)$, and $\beta$-caryophyllene (10.1\%) [23]. Similarly, the EO of Nectandra leucantha showed as the main compounds bicyclogermacrene (28.4\%), germacrene A $(7.3 \%), \alpha$-pinene $(6.6 \%)$, and $\beta$-pinene $(4.6 \%)$ [24]. The sesquiterpene $\delta$-cadinene identified in the $\mathrm{EO}$ of branches was detected as the main compound in EOs of leaf and bark of Beilschmiedia madang (17.0\% and $20.5 \%$, respectively) and was associated with germacrene D in the oil of barks of Beilschmiedia glabra $[25,26]$.

The EO of O. cujumary leaves (Cuj-L) was rich in $\beta$-caryophyllene (22.2\%) and caryophyllene oxide $(12.4 \%)$, followed by 2 -tridecanone $(7.3 \%)$ and $\delta$-cadinene $(6.6 \%)$. However, the EO of the branches (Cuj-B) was dominated by 2 -tridecanone (30.0\%), limonene (20.5\%), and $\beta$-caryophyllene $(8.1 \%)$. The occurrence of fatty acid derivatives such as 2-tridecanone in Lauraceae species is not very common. However, $\beta$-caryophyllene, caryophyllene oxide, and $\delta$-cadinene were the main compounds of the EO oil from leaves of Cryptocarya mandioccana [27].

The oils of $O$. caniculata showed predominance of sesquiterpenes of selinane and caryophyllane skeletons. In the leaves (Can-L), the main compounds were $\beta$-selinene $(20.3 \%), \beta$-caryophyllene $(18.9 \%)$, 7-epi- $\alpha$-selinene $(14.3 \%)$, and bicyclogermacrene $(10.4 \%)$; in the branches (Can-B), selin-11-en-4- $\alpha$-ol (20.6\%), $\beta$-selinene (12.1\%), 7-epi- $\alpha$-selinene (9.0\%), $\beta$-caryophyllene $(7.1 \%)$, and the phenylpropanoid $(E)$-asarone $(8.8 \%)$ were identified. Interestingly, the leaf essential oil of $O$. foetens, an endemic species of the Macronesian region (Canary Islands, Spain, and Madeira Islands, Portugal), had very little concentration of monoterpenoids or sesquiterpenoids, but was rich in ethyl $p$-coumarate [28]. 
Table 2. Chemical composition of essential oils of Ocotea species. RI ${ }^{\mathrm{Calc}}$, calculated retention index; $\mathrm{RI}^{\mathrm{Lit}}$, literature retention index.

\begin{tabular}{|c|c|c|c|c|c|c|c|c|c|c|c|}
\hline Constituents & RI $^{\text {Calc }}$ & $\mathrm{RI}^{\mathrm{Lit}}$ & Cau-L & Cau-B & Cuj-L & Cuj-B & Can-L & Can-B & Flo-L * & Ver-L * & Whi-L * \\
\hline E-2-Hexenal & 856 & 854 & & & & & & & & 1.1 & 0.8 \\
\hline$\alpha$-Thujene & 933 & 931 & & & & & & & & 0.2 & \\
\hline$\alpha$-Pinene & 936 & 932 & 9.8 & & 2.1 & & & & 22.5 & 0.7 & 12.7 \\
\hline Camphene & 956 & 953 & & & & & & & 1.7 & 0.1 & 0.3 \\
\hline Sabinene & 979 & 976 & & & & & & & & 0.1 & \\
\hline$\beta$-Pinene & 980 & 974 & 9.7 & & 1.8 & 2.2 & & & 21.3 & 0.3 & 7.3 \\
\hline Myrcene & 995 & 991 & & & & & & & 0.7 & 1.1 & 0.5 \\
\hline$\alpha$-Phellandrene & 1009 & 1005 & & & & & & & & 1 & \\
\hline p-Cymene & 1028 & 1026 & & & & & & & & 19.8 & \\
\hline Limonene & 1030 & 1024 & 2.1 & & 1.8 & 20.5 & & & 2.7 & & 1.1 \\
\hline$\beta$-Phellandrene & 1032 & 1031 & & & & & & & & 4.0 & \\
\hline 1,8-Cineole & 1033 & 1033 & & & & & & & & & 1.3 \\
\hline$\gamma$-Terpinene & 1064 & 1062 & & & & & & & & & 0.1 \\
\hline$\alpha$-Terpinolene & 1089 & 1088 & & & & & & & & & 0.1 \\
\hline$\alpha$-Pinene oxide & 1097 & 1095 & & & & & & & 0.1 & & \\
\hline Linalool & 1104 & 1098 & & & & & & & & 1.7 & \\
\hline Borneol & 1168 & 1165 & & & & & & & & 0.1 & \\
\hline Terpinen-4-ol & 1178 & 1177 & & & & & & 2.0 & & 0.2 & \\
\hline$\alpha$-Terpineol & 1191 & 1189 & & & & & & & & 0.2 & 1.3 \\
\hline Cuminal & 1238 & 1239 & & & & & & & & 0.1 & \\
\hline 2-Undecanol & 1301 & 1301 & & & 1.2 & 4.6 & & & & & \\
\hline$\delta$-Elemene & 1340 & 1335 & 2.2 & & & & & & & & \\
\hline$\alpha$-Cubebene & 1351 & 1345 & 2.0 & 2.0 & 0.8 & 2.2 & & & & & \\
\hline$\alpha$-Ylangene & 1373 & 1373 & 0.8 & & 5.1 & & & & & & \\
\hline$\alpha$-Copaene & 1377 & 1374 & 1.0 & & & & & & 0.1 & 0.1 & 0.8 \\
\hline$\beta$-Cubebene & 1392 & 1387 & 1.6 & & & & & & 0.1 & & \\
\hline$\beta$-Bourbonene & 1384 & 1387 & & & 0.7 & & & & & 0.1 & 0.1 \\
\hline$\delta$-Elemene & 1392 & 1389 & 1.5 & & 0.4 & & 1.1 & 0.8 & 0.3 & 0.7 & 0.3 \\
\hline Z-Caryophyllene & 1416 & 1408 & & & 0.3 & & & & & & \\
\hline$\beta$-Caryophyllene & 1421 & 1417 & 9.6 & 2.5 & 22.2 & 8.1 & 18.9 & 7.1 & 2.5 & 2.3 & 15.2 \\
\hline 2,5-Dimethoxy-p-cymene & 1424 & 1424 & & & & & & 0.9 & & & \\
\hline$\beta$-Copaene & 1428 & 1430 & & & 0.4 & & & & & & \\
\hline
\end{tabular}


Table 2. Cont.

\begin{tabular}{|c|c|c|c|c|c|c|c|c|c|c|c|}
\hline Constituents & $\mathrm{RI}^{\text {Calc }}$ & $\mathrm{RI}^{\mathrm{Lit}}$ & Cau-L & Cau-B & Cuj-L & Cuj-B & Can-L & Can-B & Flo-L * & Ver-L * & Whi-L * \\
\hline$\beta$-Gurjunene & 1432 & 1432 & & & & & & & & & 0.2 \\
\hline$\alpha$-trans-Bergamotene & 1436 & 1432 & & & & & 0.9 & & & & 1.9 \\
\hline$\gamma$-Elemene & 1435 & 1434 & 0.8 & & & & & & & & 0.1 \\
\hline$\alpha$-Guaiene & 1439 & 1439 & & & & & & & 0.1 & & \\
\hline Aromadendrene & 1440 & 1439 & & & & & & & & & 0.1 \\
\hline$Z$ - $\beta$-Farnesene & 1443 & 1440 & & & & & & 0.9 & & & \\
\hline Spirolepechinene & 1451 & 1449 & 0.7 & & & & 1.4 & 0.6 & & & \\
\hline$\alpha$-Humulene & 1455 & 1452 & 1.8 & 2.4 & 3.8 & 2.5 & 2.5 & 1.7 & 0.3 & 1.7 & 1.7 \\
\hline Sesquisabinene & 1458 & 1457 & & & & & & 0.9 & & & \\
\hline Dehydroaromadendrane & 1460 & 1460 & & & & & 0.6 & & & & \\
\hline$E$ - $\beta$-Farnesene & 1462 & 1458 & & & & & & & & & 0.9 \\
\hline allo-Aromadendrene & 1463 & 1461 & & & & & & & & & 0.2 \\
\hline trans-Cadina-1(6),4-diene & 1473 & 1475 & & & 0.5 & & & & & & \\
\hline$\gamma$-Selinene & 1477 & 1470 & & & & & & & & 0.2 & \\
\hline$\gamma$-Gurjunene & 1477 & 1475 & & & & & & 0.4 & & & \\
\hline$\gamma$-Muurolene & 1476 & 1478 & & & 0.8 & & & 0.7 & & & \\
\hline Widdra-2,4(14)-diene & 1483 & 1481 & & 6.5 & & & & & & & \\
\hline Germacrene D & 1484 & 1484 & 19.9 & 8.9 & 0.9 & 5.9 & & & 1.2 & 0.2 & 5.5 \\
\hline$\beta$-Selinene & 1485 & 1489 & & & 2.2 & & 20.3 & 12.1 & & 0.3 & \\
\hline Valencene & 1493 & 1491 & & & & & & & & 1.1 & \\
\hline cis- $\beta$-Guaiene & 1493 & 1492 & & 8.3 & 3.0 & & & 5.2 & & & \\
\hline trans-Muurola-4(14),5-diene & 1491 & 1493 & & & 1.1 & & & & & & \\
\hline 2-Tridecanone & 1497 & 1495 & & & 7.3 & 30.0 & & & & & \\
\hline Viridiflorene & 1493 & 1496 & & & & & 9.8 & & & & \\
\hline Bicyclogermacrene & 1500 & 1500 & 29.6 & & & & 10.4 & & & & 5.3 \\
\hline$\alpha$-Muurolene & 1499 & 1500 & & 1.7 & & & & 1.0 & 0.1 & & \\
\hline Germacrene A & 1504 & 1503 & & & & & & & & 0.2 & 2 \\
\hline$\beta$-Bisabolene & 1509 & 1505 & & & 0.6 & & & & & & \\
\hline$\delta$-Amorphene & 1509 & 1511 & 0.8 & 2.0 & & & & & & & \\
\hline$E, E-\alpha$-Farnesene & 1510 & 1508 & & & & & & & & & 0.3 \\
\hline$\gamma$-Cadinene & 1517 & 1513 & 0.9 & 5.9 & 1.6 & 3.1 & & 1.7 & 0.1 & 0.4 & 0.7 \\
\hline 7-epi- $\alpha$-Selinene & 1517 & 1520 & & 4.5 & & & 14.8 & 9.0 & & & \\
\hline
\end{tabular}


Table 2. Cont.

\begin{tabular}{|c|c|c|c|c|c|c|c|c|c|c|c|}
\hline Constituents & RI $^{\text {Calc }}$ & $\mathrm{RI}^{\mathrm{Lit}}$ & Cau-L & Cau-B & Cuj-L & Cuj-B & Can-L & Can-B & Flo-L * & Ver-L * & Whi-L * \\
\hline$\beta$-Cadinene & 1519 & 1518 & & & & & & & & 0.7 & 0.6 \\
\hline cis-Calamenene & 1523 & 1521 & & & & & & & & 0.6 & \\
\hline$\delta$-Cadinene & 1526 & 1522 & 1.4 & 13.8 & 6.6 & 4.7 & 0.6 & 3.9 & 0.2 & 0.4 & 3.7 \\
\hline trans-Cadina-1,4-diene & 1532 & 1533 & & & 0.6 & & & & & 0.2 & 0.2 \\
\hline$\alpha$-Cadinene & 1537 & 1538 & & & & & & & & & 0.1 \\
\hline$\alpha$-Calacorene & 1542 & 1544 & & & 0.9 & & & 1.5 & & 0.2 & \\
\hline Elemol & 1549 & 1549 & & & & & & & & & 0.1 \\
\hline Germacrene B & 1558 & 1559 & 1.6 & 3.3 & & & 0.8 & 0.4 & & & 0.7 \\
\hline E-Nerolidol & 1564 & 1561 & & & & & 1.4 & & & 2.5 & 3.9 \\
\hline$\beta$-Calacorene & 1564 & 1564 & & & & & & 0.7 & & 0.5 & \\
\hline$\gamma$-Asarone & 1576 & 1572 & & & & & & 0.4 & & & \\
\hline Spathulenol & 1579 & 1577 & 1.4 & & 0.5 & & 1.0 & & 6 & 8.5 & 15.3 \\
\hline Caryophyllene oxide & 1585 & 1582 & 1.0 & 2.0 & 12.4 & & 0.9 & 2.0 & & & \\
\hline Globulol & 1592 & 1590 & & & & & & 0.9 & & & \\
\hline Viridiflorol & 1597 & 1592 & & & & & & 1.2 & & & \\
\hline Carotol & 1586 & 1594 & & 2.7 & & & & & & & \\
\hline 6-Methoxyelemicin & 1601 & 1595 & & & & & & 6.3 & & & \\
\hline Guaiol & 1597 & 1600 & & & 1.2 & 4.0 & & & & 5.2 & \\
\hline Humulene epoxide II & 1608 & 1608 & & & 1.0 & & & & & 1.7 & \\
\hline Z-Asarone & 1625 & 1616 & & & & & 3.4 & & & & \\
\hline 1,10-di-epi-Cubenol & 1620 & 1618 & & 3.0 & & & & 1.4 & & & \\
\hline Junenol & 1620 & 1618 & & & & & & 0.6 & & & \\
\hline 1-epi-Cubenol & 1628 & 1627 & & 3.8 & & & & 0.4 & & 3.3 & \\
\hline Muurola-4,10(14)-dien-1 $\beta$-ol & 1628 & 1630 & & & 3.3 & & & & & & \\
\hline epi- $\alpha$-Cadinol & 1642 & 1638 & & & & & & 2.0 & & 0.5 & \\
\hline allo-Aromadendrene epoxide & 1632 & 1639 & & & 1.4 & & & & & & \\
\hline Caryophylla-4(12),8(13)-dien-5 $\beta$-ol & 1636 & 1639 & & & 3.2 & & & & & & \\
\hline$\alpha$-Muurolol & 1642 & 1644 & & 7.8 & & & & & 0.9 & 1.8 & \\
\hline Cubenol & 1646 & 1645 & & 2.2 & 1.5 & & & & & & \\
\hline
\end{tabular}


Table 2. Cont.

\begin{tabular}{|c|c|c|c|c|c|c|c|c|c|c|c|}
\hline Constituents & RI $^{\text {Calc }}$ & $\mathrm{RI}^{\mathrm{Lit}}$ & Cau-L & Cau-B & Cuj-L & Cuj-B & Can-L & Can-B & Flo-L * & Ver-L * & Whi-L * \\
\hline$\alpha$-Cadinol & 1652 & 1652 & & 2.2 & & & & & 1.8 & 1.5 & 1.8 \\
\hline Valerianol & 1654 & 1656 & & 6.8 & & & & & & & \\
\hline Selin-11-en- $4 \alpha$-ol & 1657 & 1658 & & 3.1 & & & & 20.6 & & & \\
\hline 7-epi- $\alpha$-Eudesmol & 1658 & 1662 & & & & & 4.2 & & & & \\
\hline Bulnesol & 1662 & 1666 & & & & & & & & 29.5 & \\
\hline 14-Hydroxy-(Z)-caryophyllene & 1666 & 1666 & & 2.3 & 1.5 & & 0.9 & 2.1 & & & \\
\hline E-Asarone & 1683 & 1675 & & & & & 3.6 & 8.8 & & & \\
\hline$\beta$-Sinensal & 1699 & 1699 & & & & & & & & & 0.6 \\
\hline$E, E$-Farnesylacetate & 1843 & 1843 & & & & & & & & & 10.1 \\
\hline Isohibaene & 1922 & 1923 & & & & & & & 0.7 & & \\
\hline Kaurene & 2034 & 2034 & & & & & & & 34.0 & & \\
\hline
\end{tabular}

$\mathrm{RI}^{\text {Calc }}=$ based on DB-5ms capillary column and alkane standards (C8-C32). RI ${ }^{\text {Lit }}=$ based on Adams library. * Literature data (Takaku et al., 2007 [22]). 
In order to differentiate between the analyzed Ocotea samples, a hierarchical cluster analysis using the chemical constituents was carried out and the resulting dendrogram is shown in Figure 2. According to these results, the samples were grouped in two main groups with similarity of $46.6 \%$. Group I is characterized by oils from O. caudata, O. whitei, and O. floribunda, which present high amounts of $\alpha$-pinene (9.8-22.5\%) and $\beta$-pinene (7.3-21.3\%). A higher similarity (74.1\%) was found with $O$. caudata and $O$. whitei due the proportions of $\alpha$-pinene, $\beta$-pinene, and $\beta$-caryophyllene (see Table 2 ). The main compound of $O$. floribunda oil was the diterpene kaurene (34.0\%) and it decreased its similarity level. Group II includes O. cujumary, O. caniculata, and O. veraguensis oils, the samples Cuj-L and Can-L present similar amounts of $\beta$-caryophyllene $(22.2 \%$ and $18.9 \%$, respectively). A lower similarity was found in sample Ver-L, which was rich in bulnesol (29.0\%) and $p$-cymene $(19.8 \%)$.

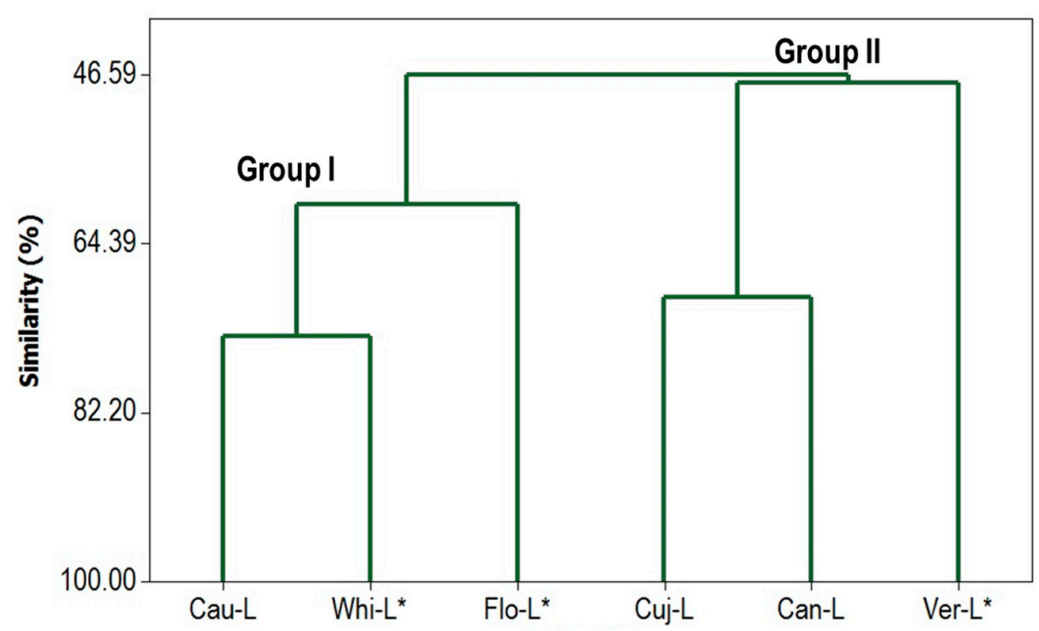

Figure 2. Dendrogram with Complete Linkage and Correlation Coefficient Distance. ${ }^{*}$ Literature data (Takaku et al., 2007 [21]).

\subsection{Antimicrobial and Cytotoxic Activities}

All essential oils displayed high antimicrobial activity against E. coli (minimum inhibitory concentration (MIC) $<19.5 \mu \mathrm{g} \cdot \mathrm{mL}^{-1}$ ). Cau-L and Cuj-L oils showed notable activity against S. epidermis and B. cereus (Table 3). It is not obvious what component(s) are responsible for the activity against $E$. coli. Most essential oil components show only marginal activity against this organism. The antibacterial activities against the other bacteria are consistent with the activities of the essential oil components (Table 3). On the other hand, the cytotoxic activity against MCF-7 cells did not display variation in the median inhibitory concentration $\left(\mathrm{IC}_{50}\right)$ values among all samples with an average of $63.0 \mu \mathrm{g} \cdot \mathrm{mL}^{-1}$ (Table 3). The main compounds germacrene $D$, bicyclogermacrene, $\beta$-caryophyllene, $\alpha$-pinene, $\beta$-pinene, caryophyllene oxide, $\beta$-selinene, 7 -epi- $\alpha$-selinene have been reported as antimicrobial and cytotoxic [29-33]. The observed cytotoxicities of some of the essential oil components are consistent with the cytotoxicities of the essential oils themselves (Table 3).

The EOs of leaves of Endlicheria arenosa, which are rich in bicyclogermacrene (42.2\%), germacrene D (12.5\%), and $\beta$-caryophyllene (10.1\%), showed the same $\mathrm{IC}_{50}$ value against Escherichia coli [23]. The EO from the leaves of Ruilopezia bracteosa (Asteraceae), with higher amounts of $\alpha$-pinene (24.3\%), 7-epi- $\alpha$-selinene $(9.1 \%)$, and $\beta$-pinene (8.5\%), showed antibacterial activity against Gram-positive and Gram-negative bacteria [34].

Terpenoids from plant oils prevent tumor cell proliferation through necrosis or induction of apoptosis [35]. Germacrene D is reported as cytotoxic against cervical carcinoma (HeLa), leukemia (HL-60), colon carcinoma (HCT), breast adenocarcinoma (SKBr), and melanoma (A2058) [36]. $\beta$-Caryophyllene and caryophyllene oxide displayed activity against several tumor cells such as breast cancer (MCF-7), colon cancer (HCT-116), and human prostate (PC-3) $[37,38]$. The values of $\mathrm{IC}_{50}$ 
of bicyclogermacrene, $\alpha$-pinene, and $\beta$-pinene against MCF-7 cells were 19.0, 30.7, and $80.2 \mu \mathrm{g} / \mathrm{mL}$, respectively [24,39].

Table 3. Antimicrobial and cytotoxic activities of Ocotea essential oils and some major essential oil components. MIC, minimum inhibitory concentration; $\mathrm{IC}_{50}$, median inhibitory concentration.

\begin{tabular}{|c|c|c|c|c|c|c|}
\hline \multirow{2}{*}{ Material } & \multicolumn{5}{|c|}{$\operatorname{MIC}\left(\mu \mathrm{g} \cdot \mathrm{mL}^{-1}\right)$} & \multirow{2}{*}{$\frac{\mathrm{IC}_{50}\left(\mu \mathrm{g} \cdot \mathrm{mL}^{-1}\right)}{\mathrm{MCF}-7}$} \\
\hline & P. aer & E. coli & S.epi & S. aur & B. cer & \\
\hline Can-L & 1250.0 & 19.5 & 625.0 & 625.0 & 625.0 & $63.9 \pm 3.7$ \\
\hline Cau-L & 1250.0 & 19.5 & 625.0 & 625.0 & 312.5 & $64.0 \pm 3.7$ \\
\hline Cuj-L & 1250.0 & 19.5 & 312.5 & 625.0 & 312.5 & $67.7 \pm 3.7$ \\
\hline$\alpha$-Pinene & 625 & 312 & - & 312 & 625 & $69.5 \pm 1.3$ \\
\hline$\beta$-Pinene & 1250 & 625 & - & 625 & 312 & $71.2 \pm 2.0$ \\
\hline Limonene & 1250 & 625 & - & 312 & 625 & $77.4 \pm 1.2$ \\
\hline$\beta$-Caryophyllene & 1250 & 312 & - & 312 & 156 & $59.4 \pm 5.1$ \\
\hline$\alpha$-Humulene & 1250 & 625 & - & 312 & 312 & $26.5 \pm 5.6$ \\
\hline Germacrene D & 1250 & 625 & - & 156 & 625 & $69.6 \pm 2.5$ \\
\hline Caryophyllene oxide & 1250 & 1250 & - & 1250 & 156 & $73.4 \pm 3.7$ \\
\hline Gentamicin control & 1.22 & 2.44 & $<19.5$ & 0.61 & 1.22 & - \\
\hline Tingenone control & $<19.5$ & $<19.5$ & - & 2.44 & 1.22 & $16.8 \pm 1.7$ \\
\hline
\end{tabular}

P. aer (Pseudomonas aeruginosa), E. coli (Escherichia coli), S. epi (Staphylococcus epidermidis), S. aur (Staphylococcus aureus), B. cer (Bacillus cereus).

\subsection{Phylogenetic Analysis}

MatK from chloroplast genes has been used as a marker for the construction of plant phylogenies, due to its rapid evolution and their ubiquitous presence in plants [40]. The sequences have a size of about 1550 bp and encode the maturase K enzyme [41].

Lauraceae species used in this study formed a defined group in the phylogenetic analysis, and the results of the phylogenetic tree were robust and supported by bootstrap value $(=100)$. Species of Calycanthaceae were used as outgroup; this corroborates with the taxonomic classification and supports the topology of the tree (Figure 3).

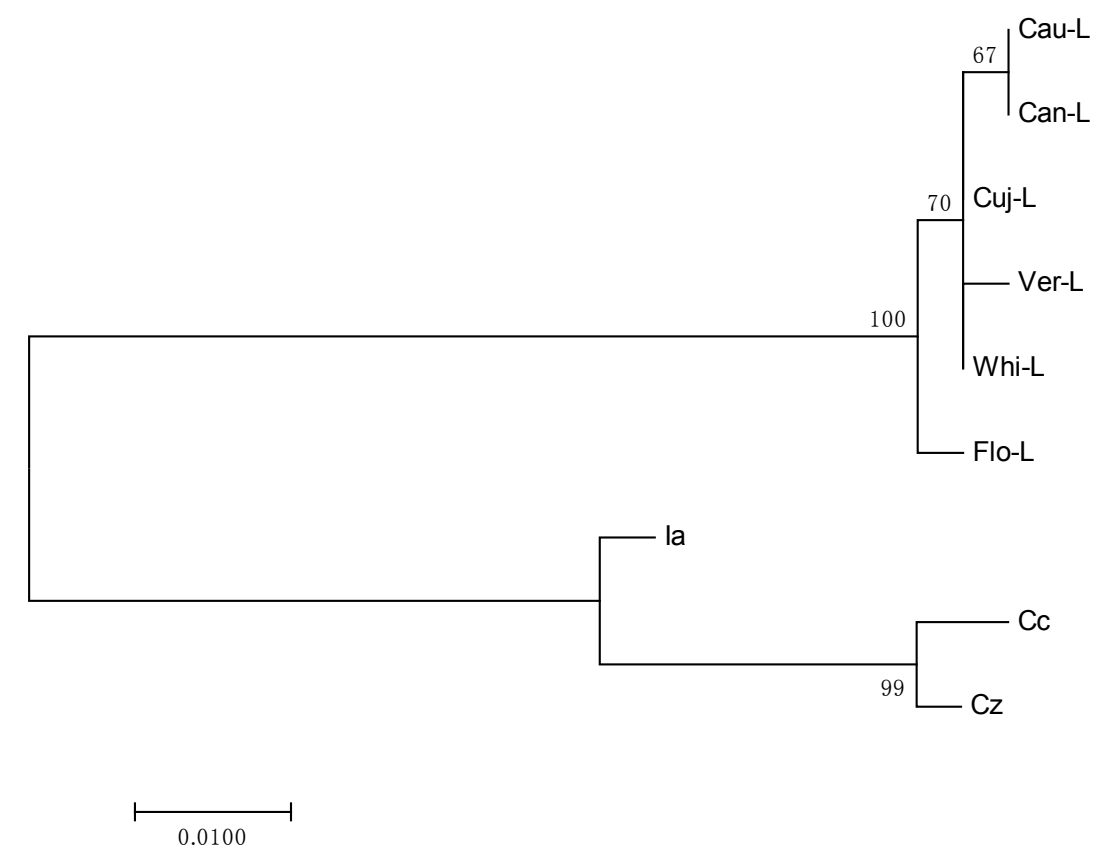

Figure 3. Molecular Phylogenetic analysis by Maximum Likelihood method for matK sequence of species of Lauraceae and Calycanthaceae (Outgroup). 
The genetic distances estimated for Lauraceae species were lower. The values ranged from 0 to 0.003 to Cau-L, Cuj-L, Can-L and from 0 to 0.009 to Ver-L, Flo-L and Whi-L.

The tree shows that the geographically closest species are grouped: Cau-L, Cuj-L, and Can-L were collected in Caxiuanã National Forest and Ver-L, Flo-L, and Whi-L were collected in Monteverde, Costa Rica. Although there may be differences in the composition of essential oils in plants of the same species with the same geographical location, the results of phylogenetic tree showed a good correlation with classes of chemical compounds. The species Cau-L and Can-L are rich in sesquiterpene hydrocarbons and the samples Cuj-L, Ver-L, and Whi-L showed similar amounts of monoterpene hydrocarbons. A higher difference could be observed for sample Flo-L, which had diterpenes as its main compound class. Our results support the hypothesis that matK gene is reasonably useful in phylogenetic reconstructions at high taxonomic levels (to order or family), but shows poorer reliability with lower taxonomic levels of classification (to genus or species) [42,43].

\section{Materials and Methods}

\subsection{Plant Material}

Leaves and branches of O. caudata (Nees) Mez, O. cujumary Mart., and O. caniculata (Rich.) Mez were collected in Caxiuanã National Forest, Marajó Island, and their vouchers were deposited in the Herbarium of Museum Paraense Emílio Goeldi, Belém, Pará state, Brazil (Table 1).

\subsection{Essential Oil Extraction}

Leaves and branches were air-dried, pulverized, and subjected to hydrodistillation using a Clevengertype apparatus (100 g, $3 \mathrm{~h}$ ). The essential oils were dried over anhydrous sodium sulfate, and the essential oil yields were calculated on the basis of the dry weight of plant material. The moisture contents of the samples were calculated after phase separation using a Dean-Stark trap ( $5 \mathrm{~g}, 60 \mathrm{~min}$ ) using toluene as the solvent phase.

\subsection{Gas Chromatographic-Mass Spectral Analysis}

The volatile compositions were analyzed by gas chromatography using an Agilent 6890 GC with an HP-5 ms column, and mass spectrometry with an Agilent 5973 mass selective detector (MSD) operated in the electron impact (EI) mode with electron energy $=70 \mathrm{eV}$. The scan range was 40-400 atomic mass units (amu) and the scan rate was 3.99 scans/s. The data were processed with an Agilent ChemStation data system. The gas chromatography (GC) column was a fused silica capillary with a ( $5 \%$ phenyl)-polymethylsiloxane stationary phase that had a film thickness of $0.25 \mu \mathrm{m}$ and a length of $30 \mathrm{~m}$, and an internal diameter of $0.25 \mathrm{~mm}$. Helium was the carrier gas with a flow rate of $1.0 \mathrm{~mL} / \mathrm{min}$ and a column head pressure of $48.7 \mathrm{kPa}$. The injector temperature was $200{ }^{\circ} \mathrm{C}$ and the detector temperature was $280^{\circ} \mathrm{C}$. The GC oven temperature was programed to start with an initial temperature of $40^{\circ} \mathrm{C}$, which was held for $10 \mathrm{~min}$. The temperature was then increased at a rate of $3{ }^{\circ} \mathrm{C} / \mathrm{min}$ to $200^{\circ} \mathrm{C}$, and then increased at $2{ }^{\circ} \mathrm{C} / \mathrm{min}$ to $220^{\circ} \mathrm{C}$. A $1-\mu \mathrm{L}$ injection of a solution $(0.2 \% \mathrm{w} / \mathrm{v}$ in $\mathrm{CH}_{2} \mathrm{Cl}_{2}$ ) of the sample was performed using a splitless injection technique. The percentages of each component were based on total ion current and are reported without standardization. Individual components were identified by comparison of both their mass spectra and GC retention data with authentic compounds present in commercial libraries [44] and our own in-house library.

\subsection{Antibacterial Assay}

The antimicrobial activity of EOs was determined against Bacillus cereus (ATCC No. 14579), Escherichia coli (ATCC No. 10798), Pseudomonas aeruginosa (ATCC No. 27853), Staphylococcus aureus (ATCC No. 29213), and Staphylococcus epidermidis (ATCC No. 12228), using the microbroth serial dilution method as previously reported [45]. Thus, $50 \mu \mathrm{L}$ of $1 \% w / v$ solution of the samples in dimethylsulfoxide (DMSO) was placed in the top well of 96-well microtiter plates and $50 \mu \mathrm{L}$ of 
cation-adjusted Mueller Hinton broth (CAMHB) was added. The sample solutions were then serially diluted (1:1) by transferring $50 \mu \mathrm{L}$ of sample-CAMHB mixture to the next lane and adding $50 \mu \mathrm{L}$ fresh CAMHB to obtain a concentration range from 2500 to $12.5 \mu \mathrm{g} \cdot \mathrm{mL}^{-1}$. The bacteria were harvested from a fresh culture and added to each well at a concentration of approximately $1.5 \times 10^{8}$ colony forming units $(\mathrm{CFU}) \cdot \mathrm{mL}^{-1}$. The plates were incubated at $37^{\circ} \mathrm{C}$ for $24 \mathrm{~h}$ and the final minimum inhibitory concentrations (MICs) were determined as the lowest concentrations free of turbidity. The antibiotic gentamicin was used as positive control and DMSO solvent was used as negative control.

\subsection{Cytotoxicity Assay}

MCF-7 human mammary adenocarcinoma cells (ATCC No. HTB-22) were cultured in RPMI (Roswell Park Memorial Institute) 1640 medium supplemented with 10\% fetal bovine serum (FBS), $30 \mathrm{mM}$ HEPES (4-(2-hydroxyethyl)-1-piperazineethanesulfonic acid buffer), $\mathrm{NaHCO}_{3}$, and penicillin streptomycin. The cytotoxicity of the essential oils on MCF-7 cells was determined using the 96-well MTT (3-(4,5-dimethylthiazol-2-yl)-2,5-diphenyltetrazolium bromide) assay as reported previously [45]. Cells were seeded into 96-well cell culture plates at a concentration of $1.2 \times 10^{4}$ cells/well and a volume of $100 \mu \mathrm{L}$ in each well. The plate was then labeled and incubated at $37{ }^{\circ} \mathrm{C}$ and $5 \% \mathrm{CO}_{2}$ for $48 \mathrm{~h}$. After $48 \mathrm{~h}$, the cells reached $70-80 \%$ confluent growth. The supernatant fluid was gently aspirated (without touching the bottom of the well to avoid removing cells) and replaced with $100 \mu \mathrm{L}$ growth medium that contained either 1.0 or $0.5 \mu \mathrm{L}$ of essential oil ( $1 \%$ in DMSO), to give final concentrations of 100 and $50 \mu \mathrm{g} \cdot \mathrm{mL}^{-1}$. The plate was then incubated at $37^{\circ} \mathrm{C}$ and $5 \% \mathrm{CO}_{2}$ for $48 \mathrm{~h}$. After $48 \mathrm{~h}$, the liquid was gently aspirated from each well. In a tube, $10 \mathrm{~mL}$ feeding medium was mixed with $2 \mathrm{~mL}$ of MTT stock solution (and was protected from light). Into each well, $100 \mu \mathrm{L}$ of the MTT solution was added and the pre-read absorbance was immediately measured spectrophotometrically at $570 \mathrm{~nm}$ (using a Molecular Devices Spectra Max Plus 384 microplate reader). Formazan crystals were formed over the course of $4 \mathrm{~h}$ at $37{ }^{\circ} \mathrm{C}$ and $5 \% \mathrm{CO}_{2}$. After $4 \mathrm{~h}$, DMSO was used to dissolve the purple crystals. The amount of MTT-formazan produced was determined spectrophotometrically at $570 \mathrm{~nm}$. Growing medium, DMSO, and tingenone $\left(100 \mu \mathrm{g} \cdot \mathrm{mL}^{-1}\right)$ served as negative, compound, and positive controls, respectively. Solutions were added to wells in eight replicates. Average absorbances, standard deviations, and percent kill ratios $\left(\% \mathrm{kill}_{\mathrm{oil}} / \% \mathrm{kill}_{\mathrm{control}}\right)$ were calculated. Median inhibitory concentrations $\left(\mathrm{IC}_{50}\right)$ were determined using the Reed-Muench method [46].

\subsection{Multivariate Statistical Analysis of Chemical Composition}

Hierarchical cluster analysis was carried out to organize and cluster the essential oils according to their main volatile constituents. Complete linkage and absolute correlation coefficient distance was chosen to determine similarity. Agglomerative hierarchical clustering was utilized for clustering the essential oils. The MINITAB 14.0 software was used to statistically analyze all data.

\subsection{DNA Isolation, PCR Amplification, and Sequencing}

Genomic DNA material was extracted from dried leaf tissue of each plant using E.Z.N.A ${ }^{\circledR}$ Poly-Gel DNA Extraction Kit (Omega Bio-tek, Norcross, GA, USA) according to the protocol given by the company. For amplification of matK region, PCR was performed in a $50 \mu \mathrm{L}$ reaction mixture that consisted of $36.5 \mu \mathrm{L}$ of nanofiltrated (NF) water, $5.0 \mu \mathrm{L}$ of $10 \times$ Advantage Buffer, $1.0 \mu \mathrm{L}$ of deoxynucleotide (DNTP), $0.5 \mu \mathrm{L}$ of Taq-DNA polymerase, $5.0 \mu \mathrm{L}$ template DNA, $1.0 \mu \mathrm{L}$ of matK-Lau001 (F-5'-TCCTTTCTTGAGCGAACACA-3'), and $1.0 \mu \mathrm{L}$ of matK-Lau002 (R-5'-CTGACAAATCGGACCGAAAC-3') primers purchased from Eurofins MWG Operon (Huntsville, AL, USA). Amplifications conditions for mat $K$ primers consisted of an initial denaturation step for $2 \mathrm{~min}$ at $95^{\circ} \mathrm{C}$, followed by 40 cycles of $30 \mathrm{~s}$ at $95^{\circ} \mathrm{C}, 30 \mathrm{~s}$ at $61^{\circ} \mathrm{C}, 60 \mathrm{~s}$ at $68^{\circ} \mathrm{C}$, and $60 \mathrm{~s}$ at $72{ }^{\circ} \mathrm{C}$ for final extension. Amplifications were performed in an Eppendorf MasterCycler Pro thermocycler, the PCR products were visualized in agarose gel $(1 \%)$, purified, and then they were sent to Eurofins MWG Operon (Huntsville, AL, USA) for sequencing. 


\subsection{Phylogenetic Analysis}

The matK sequences of O. caudata (Nees) Mez, O. cujumary Mart., and O. caniculata (Rich.) were assembled and edited using FinchTV (biomatters Ltd., Auckland, New Zealand). Sequences were checked against those in GenBank using the BLAST algorithm. The matK sequences from O. caudata (Nees) Mez, O. cujumary Mart., and O. caniculata (Rich.) were aligned with sequences from O. floribunda (gbEU153866.1), O. veraguensis (gb.JQ589849.1), and O. whitei (gb. JQ589831.1) available in GenBank. The sequences were edited using BioEdit V7.2.5 [47] and the alignment was performed using the Clustal W [48]. The distance genetic and Phylogenetic Tree was determined using Mega 7 Program [49]. The evolutionary history was inferred using the maximum likelihood method and the evolutionary distances were computed using the Kimura 2-parameter model with 10,000 replicates. The outgroups used for the construct phylogenetic tree were the matK sequences from Calycanthus chinensis (Cc) (gb | AY525339.1), Idiospermum australiense (Ia) (gi71891392), and Chimonanthus zhejiangensis (Cz) (gb | AY525341.1) belonging to the order Laurales and Calycanthaceae family.

\section{Conclusions}

In this present study, the main compounds identified in the essential oils of species collected in Caxiuanã Forest were terpenoid hydrocarbons and oxygenated terpenoids, which had good antimicrobial and cytotoxic activities. The main class of chemical compounds displayed a good correlation with chloroplast DNA region (matK gene) analysis. However, the analysis of phylogenetic data and specific chemical compounds showed differences. These results suggest that matK gene was not efficient for representing this relationship.

Acknowledgments: The authors are grateful to CNPq-Programa "Ciências sem fronteiras" (Grant No. 233761/ 2014-4) for financial support.

Author Contributions: Joyce Kelly da Silva, Leland J. Cseke, and William N. Setzer conceived and designed the experiments; Joyce Kelly da Silva, Rafaela da Trindade, Rebecca S. Miller, and Noura S. Dosoky performed the experiments; Joyce Kelly da Silva, Edith Cibelle Moreira, and William N. Setzer analyzed the data; José Guilherme Maia, Leland J. Cseke, and William N. Setzer contributed reagents/materials/analysis tools; Joyce Kelly da Silva, Rafaela da Trindade, Edith Cibelle Moreira, and William N. Setzer wrote the paper.

Conflicts of Interest: The authors declare no conflict of interest. The founding sponsors had no role in the design of the study; in the collection, analyses, or interpretation of data and in the decision to publish the results.

$\begin{array}{ll}\text { Abbreviations } \\ \text { matK } & \text { Megakaryocyte-Associated Tyrosine Kinase } \\ \text { MIC } & \text { Minimum Inhibitory Concentration } \\ \text { RI }_{\text {Calc. }} & \text { Calculated retention index } \\ \text { RI }_{\text {Lit }} & \text { Literature retention index } \\ \text { IC }_{50} & \text { Median Inhibitory Concentration } \\ \text { GC } & \text { Gas chromatography } \\ \text { DMSO } & \text { Dimethylsulfoxide } \\ \text { RPMI } & \text { Roswell Park Memorial Institute medium } \\ \text { MTT } & \text { 3-(4,5-Dimethylthiazol-2-yl)-2,5-diphenyltetrazolium bromide } \\ \text { HEPES } & \text { 4-(2-Hydroxyethyl)-1-piperazineethanesulfonic acid buffer } \\ \text { PCR } & \text { Polymerase Chain Reaction }\end{array}$

\section{References}

1. Rohwer, J.G. Lauraceae. In The Families and Genera of Vascular Plants; Kubitzki, K., Rohwer, J.G., Bittrich, V., Eds.; Springer: Berlin, Germany, 1993; Volume 2, pp. 366-391.

2. Quinet, A.; Baitello, J.B.; Moraes, P.L.R.; Alves, F.M.; Assis, L. Lauraceae. Lista de Espécies da flora do Brasil. Jardim Botânico do Rio de Janeiro. Available online: http:/ / floradobrasil.jbrj.gov.br/jabot/floradobrasil/ FB143 (accessed on 7 March 2017). 
3. Institute of Research Rio de Janeiro Botanical Garden. Lauraceae. Flora do Brasil 2020 em Construção. Jardim Botânico do Rio de Janeiro. Available online: http:/ / floradobrasil.jbrj.gov.br/reflora/floradobrasil/FB143 (accessed on 7 March 2017).

4. Van der Werff, H. A synopsis of Ocotea (Lauraceae) in Central America and southern Mexico. Ann. Mo. Bot. Gard. 2002, 89, 429-451. [CrossRef]

5. Marques, C.A. Importância econômica da família Lauraceae Lindl. Florest. Ambient. 2001, 8, 195-206.

6. David, J.M.; Yoshida, M.; Gottlieb, O.T. Phenylpropanoid-catechins from bark of Ocotea porosa. Phytochemistry 1994, 35, 545-546. [CrossRef]

7. David, J.M.; Yoshida, M.; Gottlieb, O.R. Neolignans from bark and leaves of Ocotea porosa. Phytochemistry 1994, 36, 491-499. [CrossRef]

8. Barrera, E.D.C.; Suárez, L.E.C. Aporphine Alkaloids from Leaves of Ocotea macrophylla (Kunth) (Lauraceae) from Colombia. Biochem. Syst. Ecol. 2009, 37, 522-524. [CrossRef]

9. Garcez, W.S.; Yoshida, M.; Gottlieb, O.R. Benzylisoquinoline alkaloids and flavonols from Ocotea vellosiana. Phytochemistry 1995, 39, 815-816. [CrossRef]

10. Chavez, J.P.; Gottlieb, O.R.; Yoshida, M. 10-Desmethyl-1-methyl-eudesmanes from Ocotea corymbosa. Phytochemistry 1995, 39, 849-852. [CrossRef]

11. Ballabenia, V.; Tognolinia, M.; Bertonia, S.; Brunib, R.; Guerrinib, A.; Ruedac, G.M.; Barocellia, E. Antiplatelet and antithrombotic activities of essential oil from wild Ocotea quixos (Lam.) Kosterm. (Lauraceae) calices from Amazonian Ecuador. Pharmacol. Res. 2007, 55, 23-30. [CrossRef] [PubMed]

12. Chaverri, C.; Díaz, C.; Cicció, J.F. Chemical Analysis of Essential Oils from Ocotea gomezii W.C. Burger and Ocotea morae Gómez-Laur. (Lauraceae) Collected at "Reserva Biológica Alberto M. Brenes" in Costa Rica and their Cytotoxic Activity on Tumor Cell Lines. J. Braz. Chem. Soc. 2011, 22, 741-745. [CrossRef]

13. Morais, L.C.S.L.; Barbosa-Filho, J.M.; Almeida, R.N. Central depressant effects of reticuline extracted from Ocotea duckei in rats and mice. J. Ethnopharmacol. 1998, 62, 57-61. [CrossRef]

14. Fournet, A.; Ferreira, M.E.; Arias, A.R.; Guy, I.; Guinaudeau, H.; Heinzen, H. Phytochemical and antiprotozoal activity of Ocotea lancifolia. Fitoterapia 2007, 78, 382-384. [CrossRef] [PubMed]

15. Montrucchio, D.P.; Miguel, O.G.; Zanin, S.M.; da Silva, G.A.; Cardoso, A.M.; Santos, A.R. Antinociceptive effects of a chloroform extract and the alkaloid dicentrine isolated from fruits of Ocotea puberula. Planta Med. 2012, 78, 1543-1548. [CrossRef] [PubMed]

16. Liu, Y.; Cheng, E.; Rakotondraib, L.H.; Brodie, P.J.; Applequist, W.; Randrianaivo, R.; Rakotondrafara, A.; Ratsimbason, M.; Rasamison, V.E.; Kingston, D.G.I. Antiproliferative compounds from Ocotea macrocarpa from the Madagascar dry forest. Tetrahedron Lett. 2015, 56, 3630-3632. [CrossRef] [PubMed]

17. Costa, I.F.; Calixto, S.D.; Heggdorne de Araujo, M.; Konno, T.U.; Tinoco, L.W.; Guimarães, D.O.; Lasunskaia, E.B.; Leal, I.R.; Muzitano, M.F. Antimycobacterial and Nitric Oxide Production Inhibitory Activities of Ocotea notata from Brazilian Restinga. Sci. World J. 2015, 2015, 1-9. [CrossRef] [PubMed]

18. Ballabeni, V.; Tognolini, M.; Giorgio, C.; Bertoni, S.; Bruni, R.; Barocelli, E. Ocotea quixos Lam. essential oil: In vitro and in vivo investigation on its anti-inflammatory properties. Fitoterapia 2010, 81, 289-295. [CrossRef] [PubMed]

19. MMA (Ministério do Meio Ambiente). Instrução Normativa $n^{\circ} .6$ de 23/09/2008. Reconhece as espécies da flora brasileira ameaçadas de extinção.

20. Martins, E.M.; Martinelli, G.; Arbetman, M.P.; Lamont, R.W.; Simões-Araújo, J.L.; Powell, D.; Ciampi-Guillardi, M.; Baldauf, C.; Quinet, A.; Galisa, P.; et al. Development and characterization of microsatellite loci for Ocotea species (Lauraceae) threatened with extinction. Genet. Mol. Res. 2014, 13, 5138-5142. [CrossRef] [PubMed]

21. Rahali, F.Z.; Lamine, M.; Gargouri, M.; Rebey, I.B.; Hammami, M.; Sellami, I.H. Metabolite profiles of essential oils and molecular markers analysis to explore the biodiversity of Ferula communis: Towards conservation of the endemic giant fennel. Phytochemistry 2016, 124, 58-67. [CrossRef] [PubMed]

22. Takaku, S.; Haber, W.A.; Setzer, W.N. Leaf essential oil composition of 10 species of Ocotea (Lauraceae) from Monteverde, Costa Rica. Biochem. Syst. Ecol. 2007, 35, 525-532. [CrossRef]

23. Da Silva, J.K.R.; da Trindade, R.C.; Maia, J.G.; Setzer, W.N. Chemical Composition, Antioxidant, and Antimicrobial Activities of Essential Oils of Endlicheria arenosa (Lauraceae) from the Amazon. Nat. Prod. Commun. 2016, 11, 695-698. [PubMed] 
24. Grecco, S.S.; Martins, E.G.; Girola, N.; de Figueiredo, C.R.; Matsuo, A.L.; Soares, M.G.; Bertoldo, B.C.; Sartorelli, P.; Lago, J.H. Chemical composition and in vitro cytotoxic effects of the essential oil from Nectandra leucantha leaves. Pharm. Biol. 2015, 53, 133-137. [CrossRef] [PubMed]

25. Salleh, W.M.; Ahmada, F.; Yen, K.H.; Zulkifli, R.M. Chemical Compositions and Biological Activities of Essential Oils of Beilschmiedia glabra. Nat. Prod. Commun. 2015, 10, 1297-1300. [PubMed]

26. Salleh, W.M.; Ahmada, F.; Yen, K.H. Chemical Compositions and Biological Activities of Essential Oils of Beilschmiedia glabra. Arch. Pharm. Res. 2015, 38, 485-493. [CrossRef] [PubMed]

27. Telascrea, M.; de Araújo, C.C.; Marques, M.O.M.; Facanali, R.; de Moraes, P.L.R.; Cavalheiro, A.J. Essential oil from leaves of Cryptocarya mandioccana Meisner (Lauraceae): Composition and intraspecific chemical variability. Biochem. Syst. Ecol. 2007, 35, 222-227. [CrossRef]

28. Pino, J.A.; Fernandes, P.; Marbot, R.; Sá Fontinha, S. Chemical composition of the leaf oil of Ocotea foetens (Alt.) Benth. et Hook. from Madeira. J. Essent. Oil Res. 2004, 16, 131-132. [CrossRef]

29. Schmidt, J.M.; Noletto, J.A.; Vogler, B.; Setzer, W.N. Abaco bush medicine: Chemical composition of the essential oils of four aromatic medicinal plants from Abaco Island, Bahamas. J. Herbs Spices Med. Plants 2007, 12, 43-65. [CrossRef]

30. Wright, B.S.; Bansal, A.; Moriarity, D.M.; Takaku, S.; Setzer, W.N. Cytotoxic leaf essential oils from Neotropical Lauraceae: Synergistic effects of essential oil components. Nat. Prod. Commun. 2007, 2, 1241-1244.

31. Owolabi, M.S.; Ogundajo, A.; Yusuf, K.O.; Lajide, L.; Villanueva, H.E.; Tuten, J.A.; Setzer, W.N. Chemical composition and bioactivity of the essential oil of Chromolaena odorata from Nigeria. Rec. Nat. Prod. 2010, 4, 72-78.

32. Sobral, M.V.; Xavier, A.L.; Lima, T.C.; de Sousa, D.P. Antitumor activity of monoterpenes found in essential oils. Sci. World J. 2014, 2014, 953451. [CrossRef] [PubMed]

33. Gautam, N.; Mantha, A.K.; Mittal, S. Essential Oils and Their Constituents as Anticancer Agents: A Mechanistic View. BioMed Res. Int. 2014, 2014, 154106. [CrossRef] [PubMed]

34. Alarcón, L.; Peña, A.; Velascd, J.; Baptista, J.G.; Rojas, L.; Aparicio, R.; Usubillaga, A. Chemical composition and antibacterial activity of the essential oil of Ruilopezia bracteosa. Nat. Prod. Commun. 2015, 10, 655-656. [PubMed]

35. Raut, J.S.; Karuppayil, S.M. A status review on the medicinal properties of essential oils. Ind. Crops Prod. 2014, 62, 250-264. [CrossRef]

36. Da Silva, E.B.P.; Matsuo, A.L.; Figueiredo, C.R.; Chaves, M.H.; Sartorelli, P.; Lago, J.H.G. Chemical constituents and cytotoxic evaluation of essential oils from leaves of Porcelia macrocarpa (Annonaceae). Nat. Prod. Commun. 2013, 8, 277-279. [PubMed]

37. El Hadri, A.; Del Río, M.A.G.; Sanz, J.; Coloma, A.G.; Idaomar, M.; Ozonas, B.R.; González, J.B.; Reus, M.I.S. Cytotoxic activity of $\alpha$-humulene and transcaryophyllene from Salvia officinalis in animal and human tumor cells. An. R. Acad. Nac. Farm. 2010, 76, 343-356.

38. Park, K.R.; Nam, D.; Yun, H.M.; Jang, H.J.; Sethi, G.; Cho, S.K.; Ahn, K.S. $\beta$-Caryophyllene oxide inhibits growth and induces apoptosis through the suppression of PI3K/AKT/mTOR/S6K1 pathways and ROS-mediated MAPKs activation. Cancer Lett. 2011, 312, 178-188. [CrossRef] [PubMed]

39. Santana, J.S.; Sartorelli, P.; Guadagnin, R.C.; Matsuo, A.L.; Figueiredo, C.R.; Soares, M.G.; da Silva, A.M.; Lago, J.H. Essential oils from Schinus terebinthifolius leaves-Chemical composition and in vitro cytotoxicity evaluation. Pharm. Biol. 2012, 50, 1248-1253. [CrossRef] [PubMed]

40. Hilu, K.W.; Liang, H. The MATK gene: Sequence variation and application in plant systematics. Am. J. Bot. 1997, 84, 830-839. [CrossRef] [PubMed]

41. Neuhaus, H.; Link, G. The chloroplast tRNALys (UUU) gene from mustard (Sinapis alba) contains a class II intron potentially coding for a maturase-related polypeptide. Curr. Genet. 1987, 11, 251-257. [CrossRef] [PubMed]

42. Chase, M.W.; Cowan, R.S.; Hollingsworth, P.M.; Berg, C.; Madrinan, S.; Petersen, G.; Seberg, O.; Jorgsensen, T.; Camero, K.M.; Carine, M.; et al. A Proposal for a Standardised Protocol to Barcode All Land Plants. Taxon 2007, 56, 295-299.

43. Lahaye, R.; van der Bank, M.; Bogarin, D.; Warner, J.; Pupulin, F.; Gigot, G.; Maurin, O.; Duthoit, S.; Barraclough, T.G.; Savolainen, V. DNA barcoding the floras of biodiversity hotspots. Proc. Natl. Acad. Sci. USA 2008, 105, 2923-2928. [CrossRef] [PubMed] 
44. Adams, R.P. Identification of Essential Oil Components by Gas Chromatography/Mass Spectrometry, 4th ed.; Allured Publishing Corporation: Carol Stream, IL, USA, 2007; p. 804.

45. Da Silva, J.K.R.; Gomes, M.V.S.; Maia, J.G.S.; Dosoky, N.S.; Setzer, W.N. Chemical composition and in vitro biological activities of essential oil chemotypes of Licaria rigida (Kosterm.) Kosterm. (Lauraceae). Int. J. Appl. Res. Nat. Prod. 2016, 9, 1-9.

46. Reed, L.J.; Muench, H. A simple method of estimating fifty per cent endpoints. Am. J. Hygeine 1938, 27, 493-497.

47. Hall, T.A. BioEdit: A user-friendly biological sequence alignment editor and analysis program for Windows 95/98/NT. Nucleic Acids Symp. Ser. 1999, 41, 95-98.

48. Thompson, J.D.; Higgins, D.G.; Gibson, T.J. CLUSTAL W: Improving the sensitivity of progressive multiple sequence alignment through sequence weighting, position-specific gap penalties and weight matrix choice. Nucleic Acids Res. 1994, 22, 4673-4680. [CrossRef] [PubMed]

49. Kumar, S.; Stecher, G.; Tamura, K. MEGA7: Molecular Evolutionary Genetics Analysis Version 7.0 for Bigger Datasets. Mol. Biol. Evol. 2016, 33, 1870-1874. [CrossRef] [PubMed]

(C) 2017 by the authors. Licensee MDPI, Basel, Switzerland. This article is an open access article distributed under the terms and conditions of the Creative Commons Attribution (CC BY) license (http:/ / creativecommons.org/licenses/by/4.0/). 